\title{
International differences in telecommunications demand
}

\author{
Maria Lurdes Castro Martins*
}

October 2002

Second version

\begin{abstract}
Countries with significantly different development levels experience similar regulatory transformations in the telecommunications industry. While these changes may be particularly successful in lowering costs, they may also lead to lower consumer welfare in markets in which consumers are highly sensitive to price changes. This paper assessed whether price elasticities for telecommunications demand differ between broad groups of countries according to their development levels. We provided empirical evidence of differences in estimated demand elasticities between developed and less developed countries. Our results suggest that consumers in poorer countries may experience greater welfare losses when incentive regulations are implemented.

Key Words: Telecommunications; Systems of Demand Equations; Elasticities; Cross-country Data; Regulation.

JEL Classification: L96; L51; D42; D60
\end{abstract}

\section{Introduction}

\footnotetext{
* NIMA-Núcleo de Investigação em Microeconomia Aplicada, Escola de Economia e Gestao, Universidade do Minho, Campus de Gualtar, 4710-057 Braga, Portugal. Tel.: +351-253-604510; fax: +351-253-676375; e-mail: lmartins@eeg.uminho.pt.
} 
Telecommunications are currently an important issue in the economics literature. During the early 1980 s a variety of telecommunications empirical cost models applied to American firms were published (for a review see Kiss and Lefebvre, 1987). From the mid-1980s onwards, regulatory framework models dominated the telecommunications literature (Laffont and Tirole, 1993; 2000). Attention focused on how to make regulation more efficient in a market in which flaws in information are as wide-ranging as the telecommunications industry. Together with technological expertise, achieving a good regulatory framework requires cost and demand information. Regulated firms often have better knowledge of these matters than do regulators. A recent study by Gasmi et al. (1999) established that despite efficiency gains from incentive regulatory schemes, consumers might experience significant welfare losses ${ }^{1}$. Thus, to understand the impact of regulatory reforms, it is important to analyse telecommunications demand.

Estimates of price elasticities of demand for telecommunications services are essential in measuring the social welfare level attained in any regulatory environment. The economic effects of telecommunications regulation vary across countries when there are international differences in price elasticities. Despite a large body of literature on price elasticities, there are few comparative studies on telecommunications demand at an international level.

Most empirical analyses of telecommunications demand rely on single-country time series data and cross-sectional household expenditure. Some of these studies employ data from broad groups of telecommunications services (e.g. Griffin, 1982 and Gabel and Kennet (so 3 ou mais autores se usa et al), 1993), but only a few consider other commodities (e.g. Wolak, 1996). However, other studies, such as those based on

\footnotetext{
${ }^{1}$ In a 'Pareto' sense.
} 
energy demand, apply methods that are more consistent with economic theory (e.g. Brenton, 1997; Fiebig et al., 1987; Seale et al., 1991 and Rothman et al., 1994). By applying several aggregation techniques, these latter studies draw on a complete system of demand equations. Static and dynamic versions of this method were used in the present study to obtain price elasticity estimates based on cross-country demand data, some of the demand data were observed at two points in time.

This paper aimed to analyze the extent to which price elasticities for telecommunications differ between broad groups of countries classified according to per capita income levels. To accomplish this, we employed data published in 'World Comparisons of Real Gross Domestic Product and Purchasing Power', a United Nations publication, and data from the International Telecommunications Union (ITU) on-line database.

We obtained empirical evidence of differences in demand parameter estimates between rich and poor countries. The telecommunications elasticities derived suggest that price elasticities are relatively greater in poorer countries.

Although the observed changes in regulatory regimes tend to induce cost minimization by firms and restrain monopoly power, these changes relax consumer welfare constraints (e.g. price-cap regulation ${ }^{2}$ ). When price elasticities are higher, consumers suffer significant welfare losses because incumbent firms benefit from an information rent and charge prices that are higher than their marginal costs. Our results suggest that recent regulatory trends may induce a greater social welfare loss in less developed countries.

The paper is organized as follows: section 2 introduces the system of demand equations used to obtain estimated elasticities. Section 3 describes the data and

\footnotetext{
${ }^{2}$ See Gasmi et al. (1999) for details.
} 
estimation procedures employed. Section 4 presents the empirical results. Finally, section 5 concludes with a discussion of the findings and their significance to telecommunications regulation.

\section{Methodological Issues}

This study aimed to analyze the extent to which price elasticities for telecommunications differ between rich and poor countries. To accomplish this, static restricted, static non-restricted and dynamic Almost Ideal Demand System (AIDS) specification forms were estimated. In order to evaluate how sensitive results are to alternative specifications, a logarithmic demand model is also estimated.

The Almost Ideal Demand System (AIDS) is a flexible functional form employed in many demand studies (Wan, 1998). As Deaton and Muellbauer (1980) stated, the AIDS is a system of demand equations that starts from a specific class of preferences to define a system of demand equations that satisfies the axioms of consumer choice and, by aggregation, avoids strong restrictions such as parallel linear Engel curves. The budget share of each good is a linear function of the logarithm of total expenditure and of the logarithm of prices. The AIDS model represents a flexible demand system of the Translog and PIGLOG family and can be considered as a firstorder approximation to any demand system ${ }^{3}$.

The AIDS specification for the $i^{\text {th }}$ good and expressed in share form corresponds to,

$$
w_{i}=\alpha_{i}+\beta_{i} \ln \left(\frac{M}{P}\right)+\sum_{j=1}^{n} \gamma_{i j} \ln p_{j}
$$

\footnotetext{
${ }^{3}$ See Deaton $(1974 ; 1986)$ and Deaton and Muellbauer (1980) for details.
} 
There are $n$ goods and $n$ equations, where $w_{i}$ represent consumer demand share equations which are determined by current prices $p_{j}$, consumer real income is represented by $M$ and $P$ is a price index defined by,

$$
\ln P=\alpha_{0}+\sum_{i} \ln p_{i}+0.5 \sum_{i} \sum_{j} \gamma_{i j} \ln p_{i} \ln p_{j}
$$

The property of "adding-up" is satisfied when,

$$
\sum_{i=1}^{n} \alpha_{i}=1 ; \sum_{i=1}^{n} \gamma_{i j}=0 ; \sum_{i=1} \beta_{i}=0
$$

Furthermore, homogeneity and symmetry can be expressed respectively as,

$$
\sum_{j} \gamma_{i j}=0
$$

and,

$$
\gamma_{i j}=\gamma_{j i}
$$

Finally, for preference maximization, the Slutsky substitution matrix (S), has generic element,

$$
s_{i j}=\frac{\partial q_{i}}{\partial p_{j}}+\frac{\partial q_{i}}{\partial M} q_{j},
$$

where $q_{i}$ denotes the quantity of good $i$. Matrix $\mathbf{S}$ must satisfy the symmetry and negative semi-definiteness requirements. This restriction is tested for any given estimates by looking at the eigenvalues of the Slustky matrix at every observation. This study also considered a specification that allows for a different effect when prices and income change. The dynamic specification of the AIDS model, as proposed by Anderson and Blundell (1984), supposes that consumer demand may not immediately adjust to price and income changes. In order to accommodate this, these authors propose a specification in which the shares, $w_{i}$, are determined by current 
prices $p_{j}$, and consumer real income, $M$, as well as by the previous period's disequilibrium in consumption $w_{i t-l}{ }^{L}-w_{i t-1}$.

The dynamic AIDS specification corresponds to,

$$
\begin{aligned}
& \Delta w_{i t}=\beta_{i}^{C} \Delta \ln \left(\frac{M}{P}\right)_{t}+\sum_{j} \gamma_{i j}^{C} \Delta \ln p_{j t}+ \\
& +\lambda\left[\alpha_{i}+\beta_{i}^{L} \ln \left(\frac{M}{P}\right)_{t-1}+\sum_{j} \gamma_{i j}^{L} \ln p_{j t-1}-w_{i t-1}\right]
\end{aligned}
$$

where $\Delta$ is the first-difference operator, $t$ indicates time and $\lambda$ is the adjustment coefficient ${ }^{4}$.

To check the validity of our estimates, we also estimated a logarithmic demand model. This demand specification corresponds to:

$$
\ln q_{i}=\alpha_{i}+\beta_{i} \ln M+\sum_{j=1}^{n} \gamma_{i j} \ln p_{j}
$$

where again $q_{i}$ denotes the quantity of $\operatorname{good} i, p_{i}$ is the price of good $i$ and $M$ is the consumer's expenditure. The $\gamma_{i j}$ coefficient gives the long-run price elasticity estimate for the $i^{\text {th }}$ good with respect to $p_{j}$. Despite its microeconomic and econometric weaknesses (Varian, 1990), this specification has been used in a variety of demand empirical studies of telecommunications: see the survey by Taylor (1994).

Once we obtained the static and dynamic AIDS parameter estimates, we can calculate the long-run price elasticity estimates using,

$$
e_{i j}=\frac{\frac{\partial q_{i}}{\partial p_{j}}}{\frac{q_{i}}{p_{j}}}=\frac{\partial q_{i}}{\partial \ln p_{j}} \frac{1}{q_{i}}=w_{j}+\frac{\partial w_{i}}{\partial \ln p_{j}} \frac{1}{w_{i}}-\delta_{i j}
$$

or alternatively

\footnotetext{
${ }^{4}$ Superscripts $C$ and $L$ define whether the parameter is a long-run or short-run parameter
} 


$$
e_{i j}=w_{j}+\left[\gamma_{i j}-\beta_{i}\left(\alpha_{j}+\sum_{k} \gamma_{k j} \ln p_{k}\right)\right] \frac{1}{w_{i}}-\delta_{i j} \text {, }
$$

where again $\delta_{\mathrm{ij}}$ corresponds to the Kronecker's delta and

$$
e_{i j}^{c}=e_{i j}+e_{i} w_{j}
$$

represents the compensated price elasticities for the $i$ th good with respect to $p_{j}$ and $e_{i}$ is the expenditure elasticity for good $i$.

\section{Data and Estimation Procedures}

In this paper, demand model parameters were estimated using data published in 'World Comparisons of Real Gross Domestic Product and Purchasing Power', a United Nations publication for the years 1980 and 1985, and data from the International Telecommunications Union (ITU) on-line database for the same period. Data is taken from 74 developing and developed countries covering seven groups of consumer goods and services, namely, telecommunications (1); food, beverages, tobacco; clothing and footwear (2); rents, fuel and power (3); transport (4); education and recreational activities (5); and other goods and services (6).

In the AIDS model framework, the sum of the share equations is equal to unity, leading to a singular variance-covariance matrix. This problem can be resolved by dropping one of the equations and estimating the resulting $n-1$ equations by applying Zellner's seemingly unrelated regressions estimator (SURE) ${ }^{5}$. McGuire et al. (1968) demonstrated that the estimates are invariant to the equation deleted.

\footnotetext{
${ }^{5}$ See Greene (2000) for details
} 
Although the AIDS system is non-linear, it can be linearized using the Stone price index ${ }^{6}$. Therefore, our estimation of this system is based on the Deaton-Muellbauer Iterative (DMI) procedure ${ }^{7}$. Wan (1998) showed that even when this technique produces biased estimates of the $\alpha_{i}$ and $\gamma_{i j}$ parameters, unbiased estimates of the $\beta_{i}$ parameters are produced. Hence, this technique is shown to be the most suitable procedure to adopt for these types of empirical demand models.

To test for differences in telecommunications demand between rich and poor countries, we included a dummy variable in the static AIDS model that takes a value of unity when the country's per capita gross domestic product (in US dollars at international prices) is greater than 3.500 , and otherwise zero. To validate the results obtained, three logarithmic demand models were estimated: one for all countries, another for rich countries only and the third for poor countries only.

Of the 74 countries included in the data set, 42 were observed in two time periods. Hence, we also tested the existence of fixed effects and time effects in telecommunications demand within the logarithmic demand model estimation procedure.

\section{Empirical Results}

The results for the estimation of the dynamic AIDS model are shown in Tables I and II. The results for the static models appear in Tables III and IV and Logarithmic

\footnotetext{
${ }^{6}$ The Stone's (1953) index weighs the price of each good by its budget share.

${ }^{7}$ The DMI procedure is discussed in Wan (1998). By employing Stone's index and applying SURE, we obtain estimates of alpha and gamma. These estimates are used to calculate $\ln \mathrm{P}_{t}$ and we can compute the regression of the SURE model. The DMI method consists of continuing this iterative process until convergence is achieved.
} 
demand model estimates appear in Tables V and VI. Finally, the estimates for elasticities are shown in Table VII.

The main result for the AIDS model suggests that telecommunications demand does not immediately adjust to price changes. Although the $\lambda$ parameter is not statistically significant, the likelihood ratio test statistic for this hypothesis is 37.36 . Given that the $5 \%$ critical value from the chi-squared distribution with eight degrees of freedom is 15.51, the hypothesis that there is an immediate adjustment is rejected. Thus, according to these results it seems that the existence of a negative time effect in telecommunications demand should not be rejected.

The analysis of the likelihood ratio, lagrange multiplier and Hausman statistics displayed in table $\mathrm{V}$ suggests that the time and country fixed effects logarithmic demand model is preferable for these data. This result seems to reinforce the idea that there are significant time and country-fixed effects in telecommunications demand. Thus, the hypothesis of equal demand parameters for different countries should be rejected and the presence of time effects should be considered. According to the specification that includes time and country fixed effects, the elasticity of demand for telecommunications is 1.10 , which is lower than the AIDS estimates.

The dummy variable coefficients in the static AIDS models are statistically significant at the $5 \%$ level. Thus, the hypothesis that the parameters in both groups of countries are equal is also rejected.

The dynamic AIDS model produces telecommunications elasticities that range from 2.29 in richer countries to 2.42 in poorer countries. In the static AIDS model, they range from 1.21 to 1.91 . The elasticity of demand for telecommunications in less developed countries is higher than that in rich countries for all demand specifications 
analysed. The logarithmic demand model estimated elasticities range from 1.43 in rich countries to 1.62 in poor countries.

These findings support the assumptions underlying demand theory, i.e., that demand is more elastic in smaller markets, where the diffusion process is in its initial phase, and whose elasticity decreases as the diffusion process occurs.

When price elasticities are higher in poorer countries, consumers in these countries will suffer significant welfare losses if incentive regulation is implemented because incumbent firms benefit from information rents and can charge prices above their marginal costs. Thus, our results suggest that actual regulatory trends will lead to social welfare losses in less developed countries. In these countries, consumers usually have less power to favourably influence regulatory agencies ${ }^{8}$ and firms have higher rents and rates of return, leading to lower consumer welfare.

\footnotetext{
${ }^{8}$ For details, see Laffont et al. (1993).
} 
Table I - "Dynamic AIDS model estimates"

\begin{tabular}{|c|c|c|c|}
\hline Parameters & Estimates & Parameters. & Estimates \\
\hline$\alpha_{i}$ & $\begin{array}{l}-0.0475^{*} \\
(-2.57)^{*} \\
(0.01)^{* *}\end{array}$ & $\lambda$ & $\begin{array}{l}-0.1828 \\
(-0.42) \\
(0.68)\end{array}$ \\
\hline$\beta_{i}{ }^{C}$ & $\begin{array}{l}0.0004 \\
(0.00) \\
(0.97)\end{array}$ & $\beta_{i}{ }^{L}$ & $\begin{array}{l}0.0471^{*} \\
(3.65) \\
(0.00)\end{array}$ \\
\hline$\gamma_{1 j}{ }^{C}$ & $\begin{array}{l}0.0102^{*} \\
(2.86)\end{array}$ & $\gamma_{1 j}^{\mathbf{L}}$ & $\begin{array}{l}0.0047 \\
(1.38)\end{array}$ \\
\hline$\gamma_{2 j}^{C}$ & $\begin{array}{l}0.0201^{*} \\
(2.33)\end{array}$ & $\gamma_{2 j}^{\mathrm{L}}$ & $\begin{array}{l}0.0229^{*} \\
(3.20)\end{array}$ \\
\hline$\gamma_{3 j}{ }^{C}$ & $\begin{array}{l}0.0033 \\
(0.89)\end{array}$ & $\gamma_{3 j}^{L}$ & $\begin{array}{l}0.0130^{*} \\
(3.62)\end{array}$ \\
\hline & $(0.38)$ & & $(0.00)$ \\
\hline$\gamma_{4 j}^{C}$ & $\begin{array}{l}0.0073 \\
(1.48)\end{array}$ & $\gamma_{4 j}^{\mathrm{L}}$ & $\begin{array}{l}0.0132^{*} \\
(1.95)\end{array}$ \\
\hline & $(0.14)$ & & $(0.05)$ \\
\hline$\gamma_{5 j}^{C}$ & $\begin{array}{l}-0.0017 \\
(-0.37) \\
(0.71)\end{array}$ & $\gamma_{5 j}^{L}$ & $\begin{array}{l}-0.0168^{*} \\
(-2.57) \\
(0.01)\end{array}$ \\
\hline$\gamma_{6 j}{ }^{C}$ & $\begin{array}{l}{ }^{-0.0391} \\
(-4.78) \\
(0.00)\end{array}$ & $\gamma_{6 j}{ }^{L}$ & $\begin{array}{l}-0.0270^{*} \\
(-3.37) \\
(0.00)\end{array}$ \\
\hline $\ln L$ & 158.98 & $\mathbf{D W}=1.95$ & $\mathbf{N}=41$ \\
\hline
\end{tabular}

The first number inside brackets is the " $t$-value". The second number inside brackets is the "P-value". "Indicates significance at the $\alpha=0.05$ level.

${ }^{* *}$ Indicates significance at the $\alpha=0.1$ level. 
Table II - "Adjustment hypothesis results"

\begin{tabular}{|cc|}
\hline Hypothesis & $\lambda=1, \beta_{\mathrm{i}}{ }^{\mathrm{C}}=\beta_{\mathrm{i}}{ }^{\mathrm{L}}$ and $\gamma_{\mathrm{ij}}{ }^{\mathrm{C}}=\gamma_{\mathrm{ij}}{ }^{\mathrm{L}}$ \\
\hline $\ln \mathbf{L} r$ & 140.30 \\
$\ln \mathbf{L} u r$ & 158.98 \\
$\mathbf{L R}$ & 37.36 \\
restrictions & 8 \\
$\boldsymbol{\chi}_{\mathbf{0}}^{\mathbf{2}}$ & 20.09 \\
$\chi_{\mathbf{0} 0 \mathbf{0 1}}^{2}$ & 15.51 \\
\hline
\end{tabular}


Table III - "Static AIDS model estimates"

\begin{tabular}{|c|c|c|c|c|c|c|}
\hline & $\begin{array}{l}\text { Telec. } \\
\text { (1) }\end{array}$ & $\begin{array}{l}\text { Food, } \\
\text { Clothing } \\
(2)\end{array}$ & $\begin{array}{c}\text { Rent. Fuel. } \\
\text { Power } \\
\text { (3) }\end{array}$ & $\begin{array}{l}\text { Transp. } \\
\text { (4) }\end{array}$ & $\begin{array}{c}\text { Rec.Educ. } \\
\text { (5) }\end{array}$ & $\begin{array}{c}\text { Others } \\
\text { (6) }\end{array}$ \\
\hline$\alpha_{i}$ & $\begin{array}{l}0.0010 \\
(0.12) \\
(0.91) \\
\end{array}$ & $\begin{array}{l}0.8020 * \\
(12.94) \\
(0.00) \\
\end{array}$ & $\begin{array}{c}-0.0289 \\
(-0.74) \\
(0.46) \\
\end{array}$ & $\begin{array}{l}0.0668 * * \\
(2.31) \\
(0.02) \\
\end{array}$ & $\begin{array}{l}0.1080 * \\
(3.13) \\
(0.00) \\
\end{array}$ & $\begin{array}{l}0.0508 \\
(1.20) \\
(0.23) \\
\end{array}$ \\
\hline \multirow[t]{2}{*}{$\beta_{i}$} & $\begin{array}{l}0.0028 \\
(0.95)\end{array}$ & $\begin{array}{l}-0.1327^{*} \\
(-6.65)\end{array}$ & $\begin{array}{c}0.0471 * \\
(3.61)\end{array}$ & $\begin{array}{l}0.0045 \\
(0.47)\end{array}$ & $\begin{array}{l}0.0076 \\
(0.69)\end{array}$ & $\begin{array}{l}0.0708 * \\
(5.06)\end{array}$ \\
\hline & $(0.34)$ & $(0.00)$ & $(0.00)$ & $(0.64)$ & $(0.49)$ & $(0.00)$ \\
\hline \multirow[t]{2}{*}{$\gamma_{1 j}$} & $\begin{array}{l}-0.0049 * \\
(-4.13)\end{array}$ & $\begin{array}{l}0.0052 \\
(1.51)\end{array}$ & $\begin{array}{c}-0.0009 \\
(-0.52)\end{array}$ & $\begin{array}{l}0.0062 * \\
(3.09)\end{array}$ & $\begin{array}{l}-0.0009 \\
(-0.42)\end{array}$ & $\begin{array}{l}-0.0046 \\
(-1.47)\end{array}$ \\
\hline & $(0.00)$ & $(0.13)$ & $(0.60)$ & $(0.00)$ & $(0.68)$ & $(0.14)$ \\
\hline \multirow[t]{2}{*}{$\gamma_{2 j}$} & & $\begin{array}{l}-0.0132 \\
(-0.44)\end{array}$ & $\begin{array}{c}0.0670^{*} \\
(5.84)\end{array}$ & $\begin{array}{l}-0.0223 \\
(-1.85)\end{array}$ & $\begin{array}{l}-0.0366^{*} \\
(-2.73)\end{array}$ & $\begin{array}{l}-0.0001 \\
(-0.01)\end{array}$ \\
\hline & & $(0.66)$ & $(0.00)$ & $(0.06)$ & $(0.01)$ & $(0.99)$ \\
\hline \multirow[t]{2}{*}{$\gamma_{3 \mathbf{j}}$} & & & $\begin{array}{c}-0.0248 * \\
(-3.28)\end{array}$ & $\begin{array}{l}-0.0038 \\
(-0.71)\end{array}$ & $\begin{array}{l}0.0002 \\
(0.03)\end{array}$ & $\begin{array}{l}-0.0376^{*} \\
(-4.69)\end{array}$ \\
\hline & & & $(0.00)$ & $(0.48)$ & $(0.98)$ & $(0.00)$ \\
\hline \multirow[t]{2}{*}{$\gamma_{4 j}$} & & & & $\begin{array}{l}0.0081 \\
(0.95)\end{array}$ & $\begin{array}{l}-0.0001 \\
(-0.01)\end{array}$ & $\begin{array}{l}0.0119 \\
(1.33)\end{array}$ \\
\hline & & & & $(0.34)$ & $(0.99)$ & $(0.19)$ \\
\hline \multirow[t]{2}{*}{$\gamma_{5 j}$} & & & & & $\begin{array}{l}0.0202 \\
(1.90)\end{array}$ & $\begin{array}{l}0.0172 \\
(1.66)\end{array}$ \\
\hline & & & & & $(0.06)$ & $(0.10)$ \\
\hline \multirow[t]{2}{*}{$\gamma_{6 j}$} & & & & & & $\begin{array}{l}0.0133 \\
(0.73)\end{array}$ \\
\hline & & & & & & $(0.46)$ \\
\hline \multirow[t]{2}{*}{$\mathbf{d}_{\mathrm{i}}$} & $\begin{array}{l}0.0069 * \\
(2.69)\end{array}$ & $\begin{array}{l}-0.0947 * \\
(-4.59)\end{array}$ & $\begin{array}{c}0.0039 \\
(0.30)\end{array}$ & $\begin{array}{l}0.0320 * \\
(3.27)\end{array}$ & $\begin{array}{l}0.0368 * \\
(3.15)\end{array}$ & $\begin{array}{l}0.0151 \\
(1.03)\end{array}$ \\
\hline & $(0.01)$ & $(0.00)$ & $(0.76)$ & $(0.00)$ & $(0.00)$ & $(0.30)$ \\
\hline $\log \mathrm{L}$ & 1237.7 & & $\mathrm{~N}=116$ & & & \\
\hline
\end{tabular}

The first number inside brackets is the " $\mathrm{t}$-value". The second number inside brackets is the "Pvalue".* Indicates significance at the $\alpha=0.05$ level. ** Indicates significance at the $\alpha=0.1$ level. 
Table IV- "Non-Restricted AIDS model estimates"

\begin{tabular}{|c|c|}
\hline Parameters & Estimates \\
\hline$\alpha_{1}$ & $\begin{array}{l}-0.013 \\
(-1.37) \\
(0.17)\end{array}$ \\
\hline$\beta_{1}$ & $\begin{array}{l}0.007^{*} \\
(2.34) \\
(0.02)\end{array}$ \\
\hline$\gamma_{1}$ & $\begin{array}{l}-0.003^{*} \\
(-2.05) \\
(0.04)\end{array}$ \\
\hline$\gamma_{2}$ & $\begin{array}{l}0.005 \\
(1.49) \\
(0.14)\end{array}$ \\
\hline$\gamma_{3}$ & $\begin{array}{l}0.001 \\
(0.40) \\
(0.69)\end{array}$ \\
\hline$\gamma_{4}$ & $\begin{array}{l}0.006^{*} \\
(2.56) \\
(0.01)\end{array}$ \\
\hline$\gamma_{5}$ & $\begin{array}{l}-0.003 \\
(-1.09) \\
(0.28)\end{array}$ \\
\hline$\gamma_{6}$ & $\begin{array}{l}-0.003 \\
(-0.80) \\
(0.42)\end{array}$ \\
\hline$d_{1}$ & $\begin{array}{l}0.006^{*} \\
(2.15) \\
(0.03)\end{array}$ \\
\hline $\mathbf{R}^{2}=0.48$ & $\mathrm{~N}=116$ \\
\hline
\end{tabular}

The first number inside brackets is the "t-value". The second number inside brackets is the "P-value". " Indicates significance at the $\alpha=0.05$ level. ${ }^{* *}$ Indicates significance at the $\alpha=0.1$ level. 
Table V - "Logarithmic demand model estimates"

\begin{tabular}{|c|c|c|c|c|c|}
\hline Parameters & $\begin{array}{l}\text { Without } \\
\text { effects (1) }\end{array}$ & $\begin{array}{c}\text { Fixed } \\
\text { effects } \\
\text { model (2) }\end{array}$ & $\begin{array}{c}\text { Random } \\
\text { effects model } \\
\text { (3) }\end{array}$ & $\begin{array}{c}\text { Fixed and } \\
\text { time effects } \\
\text { (4) }\end{array}$ & $\begin{array}{c}\text { Random and } \\
\text { time effects } \\
\text { (5) }\end{array}$ \\
\hline$\alpha_{I}$ & $\begin{array}{l}-9.7 \\
(-10.17) \\
(0.00)\end{array}$ & & $\begin{array}{l}-10.02 \\
(-10.11) \\
(0.00)\end{array}$ & $\begin{array}{l}-11.97 \\
(-3.32) \\
(0.00)\end{array}$ & $\begin{array}{l}-9.85 \\
(-9.49) \\
(0.00)\end{array}$ \\
\hline \multirow[t]{2}{*}{$\beta_{I}$} & $\begin{array}{l}1.59 \\
(14.31)\end{array}$ & $\begin{array}{l}2.35 \\
(5.56)\end{array}$ & $\begin{array}{l}1.62 \\
(13.80)\end{array}$ & $\begin{array}{l}1.86 \\
(4.33)\end{array}$ & $\begin{array}{l}1.61 \\
(13.75)\end{array}$ \\
\hline & $(0.00)$ & $(0.00)$ & $(0.00)$ & $(0.00)$ & $(0.00)$ \\
\hline$\gamma_{1 j}$ & $\begin{array}{l}-1.67 \\
(-10.51) \\
(0.00)\end{array}$ & $\begin{array}{l}-1.52 \\
(-6.71) \\
(0.00)\end{array}$ & $\begin{array}{l}-1.69 \\
(-11.20) \\
(0.00)\end{array}$ & $\begin{array}{l}-1.10 \\
(-4.23) \\
(0.00)\end{array}$ & $\begin{array}{l}-1.15 \\
(-6.61) \\
(0.00)\end{array}$ \\
\hline$\gamma_{2 j}$ & $\begin{array}{l}0.89 \\
(2.33) \\
(0.02)\end{array}$ & $\begin{array}{l}1.78 \\
(2.45) \\
(0.02)\end{array}$ & $\begin{array}{l}1.15 \\
(3.17) \\
(0.00)\end{array}$ & $\begin{array}{l}1.77 \\
(2.64) \\
(0.01)\end{array}$ & $\begin{array}{l}0.81 \\
(2.24) \\
(0.02)\end{array}$ \\
\hline$\gamma_{3 \mathbf{j}}$ & $\begin{array}{l}-0.03 \\
(-0.15) \\
(0.88)\end{array}$ & $\begin{array}{l}-0.25 \\
(-0.96) \\
(0.34)\end{array}$ & $\begin{array}{l}-0.17 \\
(-0.92) \\
(0.36)\end{array}$ & $\begin{array}{l}-0.06 \\
(-0.25) \\
(0.81)\end{array}$ & $\begin{array}{l}0.003 \\
(0.02) \\
(0.95)\end{array}$ \\
\hline$\gamma_{4 j}$ & $\begin{array}{l}0.67 \\
(2.35)\end{array}$ & $\begin{array}{l}0.07 \\
(0.15)\end{array}$ & $\begin{array}{l}0.63 \\
(2.34)\end{array}$ & $\begin{array}{l}-0.56 \\
(-1.13)\end{array}$ & $\begin{array}{l}-0.20 \\
(-0.66)\end{array}$ \\
\hline$\gamma_{5 j}$ & $\begin{array}{l}-0.41 \\
(-1.22) \\
(0.22)\end{array}$ & $\begin{array}{l}0.76 \\
(1.23) \\
(0.22)\end{array}$ & $\begin{array}{l}-0.27 \\
(-0.84) \\
(0.40)\end{array}$ & $\begin{array}{l}0.67 \\
(1.18) \\
(0.24)\end{array}$ & $\begin{array}{l}-0.001 \\
(-0.00) \\
(0.99)\end{array}$ \\
\hline$\gamma_{6 j}$ & $\begin{array}{l}-0.49 \\
(-1.06) \\
(0.29)\end{array}$ & $\begin{array}{l}-1.38 \\
(-1.35) \\
(0.18)\end{array}$ & $\begin{array}{l}-0.70 \\
(-1.51) \\
(0.13)\end{array}$ & $\begin{array}{l}-1.61 \\
(-1.70) \\
(0.09)\end{array}$ & $\begin{array}{l}-0.50 \\
(-1.1) \\
(0.27)\end{array}$ \\
\hline $\begin{array}{l}\text { Likelihood } \\
\text { Ratio test }\end{array}$ & $L R$ & $\begin{array}{l}\text { Degrees of } \\
\text { freedom }\end{array}$ & Prob. & & \\
\hline $\begin{array}{l}\text { (2) } v s(1) \\
\text { (4) } v s(2) \\
\text { (4) } v s(1)\end{array}$ & $\begin{array}{l}198 \\
22.17 \\
220\end{array}$ & $\begin{array}{l}73 \\
1 \\
75\end{array}$ & $\begin{array}{l}0.00 \\
0.00 \\
0.00\end{array}$ & & \\
\hline $\begin{array}{l}\text { Lagrange } \\
\text { Multiplier }\end{array}$ & $M L$ & $\begin{array}{l}\text { Degrees of } \\
\text { freedom }\end{array}$ & Prob. & & \\
\hline $\begin{array}{l}(2)(3) v s \\
(1) \\
(4)(5) v s \\
(1)\end{array}$ & $\begin{array}{l}0.65 \\
29.87\end{array}$ & 2 & $\begin{array}{l}0.42 \\
0.00\end{array}$ & & \\
\hline \multicolumn{6}{|l|}{ Hausman } \\
\hline (4) vs (5) & 16.31 & 7 & 0.02 & & \\
\hline
\end{tabular}

The first number inside brackets is the "t-value". The second number inside brackets is the "P-

value". "Indicates significance at the $\alpha=0.05$ level. ${ }^{* *}$ Indicates significance at the $\alpha=0.1$ level. 
Table VI- "Logarithmic demand model estimates"

\begin{tabular}{|llll|}
\hline \multicolumn{3}{|c|}{ Rich countries } & \multicolumn{2}{c|}{ Poor countries } \\
\hline Parameters & Estimates & Parameters. & Estimates \\
\hline$\alpha_{1}$ & $-11.16^{*}$ & $\alpha_{1}$ & $-9.19^{*}$ \\
& $(-2.80)$ & & $(-6.56)$ \\
& $(0.01)$ & & $(0.00)$ \\
\hline$\beta_{1}$ & $1.77^{*}$ & $\beta_{1}$ & $1.46^{*}$ \\
& $(3.99)$ & & $(7.87)$ \\
& $(0.00)$ & & $(0.00)$ \\
\hline$\gamma_{1}$ & $-\mathbf{1 . 4 3}$ & $\gamma_{1}$ & $-1.62^{*}$ \\
& $(-5.73)$ & & $(-7.66)$ \\
& $(0.00)$ & & $(0.00)$ \\
\hline$\gamma_{\mathbf{2}}$ & -0.17 & $\gamma_{\mathbf{2}}$ & $1.37^{*}$ \\
& $(-0.28)$ & & $(2.63)$ \\
& $(0.78)$ & & $(0.01)$ \\
\hline$\gamma_{\mathbf{3}}$ & $-0.68^{*}$ & $\gamma_{\mathbf{3}}$ & 0.01 \\
& $(-2.17)$ & & $(0.04)$ \\
& $(0.04)$ & & $(0.97)$ \\
\hline$\gamma_{\mathbf{4}}$ & $1.15^{*}$ & $\gamma_{\mathbf{4}}$ & 0.50 \\
& $(2.39)$ & & $(1.41)$ \\
& $(0.02)$ & & $(0.16)$ \\
\hline$\gamma_{\mathbf{5}}$ & $1.13^{* *}$ & $\gamma_{\mathbf{5}}$ & $-0.77^{* *}$ \\
& $(1.96)$ & & $(-1.83)$ \\
& $(0.06)$ & & $(0.07)$ \\
\hline$\gamma_{\mathbf{6}}$ & $-1.11^{* *}$ & $\gamma_{\mathbf{6}}$ & -0.50 \\
& $(-1.67)$ & & $(-0.80)$ \\
& $(0.10)$ & & $(0.43)$ \\
\hline $\mathbf{R}^{2}=0.96$ & $\mathrm{~N}=43$ & $\mathbf{R}^{2}=0.90$ & $\mathbf{N}=72$ \\
\hline
\end{tabular}

The first number inside brackets is the "t-value". The second number inside brackets is the "P-value". " Indicates significance at the $\alpha=0.05$ level. ${ }^{* *}$ Indicates significance at the $\alpha=0.1$ level. 
Table VII - "Price elasticities of telecommunications demand"

\begin{tabular}{|c|c|c|c|c|}
\hline \multirow{2}{*}{$\begin{array}{c}\text { Average price elasticities } \\
\text { Static }\end{array}$} & \multicolumn{2}{|c|}{1980} & \multicolumn{2}{|c|}{1985} \\
\hline & $\overline{e_{11}}$ & $\mathbf{e}_{11} \mathrm{c}$ & $\mathbf{e}_{11}$ & $\mathbf{e}_{11}{ }^{c}$ \\
\hline Restricted Model & & & & \\
\hline Rich countries & 1.298 & 1.275 & 1.229 & 1.201 \\
\hline Other countries & 1.854 & 1.837 & 1.278 & 1.252 \\
\hline \multicolumn{5}{|l|}{ Non-Restricted Model } \\
\hline Rich countries & 1.330 & 1.309 & 1.208 & 1.180 \\
\hline Other countries & 1.905 & 1.896 & 1.382 & 1.363 \\
\hline \multicolumn{5}{|l|}{ Dynamic Model } \\
\hline Rich countries & & & 2.29 & 2.38 \\
\hline Other countries & & & 2.42 & 2.50 \\
\hline
\end{tabular}




\section{Conclusion}

In this paper, by estimating alternative systems of demand equations and using crosscountry consumption data, we provided evidence that price elasticities are greater in less developed countries. Similar results have been obtained in studies that analyse different industries (see Fiebig et al., 1987; Seale et al., 1991; Rothman et al., 1994). This study's results seem to reinforce the idea that there are significant time and country fixed effects in telecommunications demand. Thus, telecommunications regulation agencies should take into account demand differences between rich and poor countries. These differences prove crucial in the study of telecommunications policy. In markets as highly regulated as telecommunications, these demand differences can translate into significant welfare losses for telecommunications consumers in less developed countries.

Given emerging telecommunications markets and weaker consumer interest groups, less developed countries also have less power to influence regulatory agency decisions, and as a consequence, are more likely to incur significant welfare losses. These results, however, should be interpreted with caution due to the relatively small sample size used. Clearly, further research, possibly involving the use of different data sets, should be directed towards the analysis of differences in demand types between broad groups of countries in order to ascertain the validity of the findings presented here. 


\section{Acknowledgements}

Comments and suggestions of Paulo Guimarães, António Nogueira Leite and an anonymous referee were very helpful. Remaining errors are mine. 


\section{References}

Anderson, G. and Blundell, R. 1984, Consumer non-durables in the UK: a dynamic demand system, The Economic Journal 94, 33-44.

Brenton, P. 1997, Estimates of demand for energy using cross-country consumption data, Applied Economics 29, 851-859.

Deaton, A. 1974, The analysis of consumer demand in the United Kingdom, 19001970, Econometrica 42, 341-367.

Deaton, A. 1986, Demand analysis, in: Z. Griliches and M. Intriligator, eds., Handbook of econometrics, Vol. 3 (Elsevier Science Pub., Amsterdam) 1767-1839.

Deaton, A. and Muellbauer, J. 1980, An almost ideal demand system, American Economic Review 70, 312-326.

Fiebig, D., Seale, J. and Theil, H. 1987, The demand for energy: evidence from a cross-country demand system, Energy Economics 9, 149-153.

Gabel, D. and Kennet, D. 1993, Pricing of telecommunications services, Review of Industrial Organization 8, 1-14.

Gasmi, F., Laffont, J. and Sharkey, W. 1999, Empirical evaluation of regulatory regimes in local telecommunications markets, Journal of Economics and Management Strategy 8, 61-93.

Greene, W. 1997, Econometric analysis (Prentice-Hall International, New Jersey). Griffin, J. 1982, The welfare implications of externalities and price elasticities for telecommunications pricing, The Review of Economics and Statistics 64, 59-66.

Kiss, F and Lefebvre, B. 1987, Econometric models of telecommunications: a survey, Revue Economique 2, 307-374. 
Laffont, J. and Tirole, J. 1993, A theory of incentives in procurement and regulation (MIT Press, London).

Laffont, J. and Tirole, J. 2000, Competition in telecommunications (MIT Press, London).

Mas-Collel, A., Whinston, M. and Green, J. 1995, Microeconomic theory (Oxford University Press, New York).

McGuire, T., Farley, J., Lucas, R. and Winston, R. 1968, Estimation and inference for linear models in which subsets of the dependent variable are constrained, Journal of the American Statistical Association 63, 1201-1213.

Pereira, P. 1991, Telephone demand: a theoretical approach and its application to the Portuguese case (Working Paper 175, Universidade Nova de Lisboa).

Rothman, D., J. Hong and Mount, T. 1994, Estimating consumer energy demand using international data: theoretical and policy implications, The Energy Journal 15, $67-88$.

Seale, J., W. Walker and Kim, I. 1991, The demand for energy: cross-country evidence from the Florida model, Energy Economics 12, 33-40.

Taylor, L., 1994, Telecommunications demand in theory and practice (Kluwer Academic Publisher, Dordrecht).

Varian, H. 1990, Microeconomic analysis (North-Holland, Amsterdam).

Wan, G. 1998, Linear estimation of the nonlinear almost ideal demand system: a Monte Carlo study, Applied Economics Letters 5, 181-186.

Wolak, F. 1996, Can universal service survive in a competitive telecommunications environment? Evidence from the United States consumer expenditure survey, Information Economics and Policy 8, 163-203. 